\title{
Effect of Evodiae Fructus and Arecae Semen Mixture on Esophageal Mucosa in Chronic Acid Reflux Esophagitis
}

\author{
Jin A Lee ${ }^{1, *}$, Mi-Rae Shin ${ }^{1, * *}$, Hae-Jin Park ${ }^{2, * *}$ and Seong-Soo Roh ${ }^{1, ; ; * *}$ \\ ${ }^{I}$ Department of Herbology, College of Korean Medicine, Daegu Haany University, Daegu 42158, Korea \\ ${ }^{2}$ DHU Bio Convergence Testing Center, Gyeongsangbuk-do 38610, Korea
}

\begin{abstract}
Reflux esophagitis (RE) is a disease that stomach contents, stomach acid, and pepsin continually refluxing and is curently increasing worldwide. This study was conducted to find natural materials that can reduce side effects and effectively treat RE. Animal experiments were conducted with a 1:1 (EA1), 1:5 (EA5) ratio of Evodiae Fructus and Arecae Semen known to be effective against reflux esophagitis. As a result of confirming the total lesion of the esophageal mucosa after EA1 or EA5 treatment in reflux esophagitis animals, it showed superior improvement compared to the REcontrol rats. In addition, by regulating the expression of MPO and NADPH oxidase, the activation of NF- $\mathrm{BB}$ was inhibited, and the expression of COX-1 and COX-2 was regulated. Moreover, its improved esophageal barrier function through regulating protein expressions of tight junction protein and MMPs/TIMPs. Taken together, a mixture of Evodiae Fructus and Arecae Semen can attenuate the damage to the esophageal mucosa that not only inactivationed the NF- $\mathrm{B}$ through oxidative stress control, but also by regulating tight junctions and MMPs/TIMPs. This effect was more excellent in the 1:1 mixture (EA1) than in the Evodiae Fructus and Arecae Semen 1:5 mixture (EA5).
\end{abstract}

Key Words: Chronic acid reflux esophagitis, Evodiae Fructus, Arecae Semen, Inflammation, Tight junction

\section{서 론}

역류성 식도염(Reflux esophagitis; RE)이란 여러 가지 원 인에 의하여 위산이 역류해 점막 손상 및 염증을 초래하 는 질환으로, 연하곤란(dysphagia), 속쓰림(heart burn), 역류 증상(regurgitation) 등의 증상을 동반한다(Yi et al., 1994). $\mathrm{RE}$ 는 서구에서 발생 빈도가 높게 나타나고 있으며, 서양 인에 비하여 아시아인들은 위산분비능이 낮고, 비만환자 가 적으며, 높은 하부식도 괄약근압이 높은 등의 이유로 발생 빈도가 낮게 나타나고 있으나(Baek et al., 2004) 최근 국내에서도 조이는 복장, 흡연, 탄산음료의 빈번한 섭취
등의 생활습관 및 지방식이로 인한 비만인구 증가로 인 해 RE의 발생 빈도가 증가하고 있다(Baek et al., 2004). $\mathrm{RE}$ 치료를 위하여 위산 분비를 억제시켜주는 $\mathrm{H}_{2}$ 수용체 차단제 및 PPIs 제제 등의 처방이 많이 이루어지고 있으 나 이러한 제제들은 표준 용량 및 유지 치료 기간에 대 한 정보가 불명확하며, 복용을 중단할 경우 $\mathrm{RE}$ 환자에서 1 년 이내 50 80\%가 재발하는 것으로 알려져 있어 재발 방지를 위한 장기간 치료에도 부작용이 적은 치료제의 개 발이 필요한 실정이다(Kim et al., 2011).

오수유(吳茱莫; Evodiae Fructus)는 운향과(芸香科; Rutaceae)에 속하는 오수유의 미성숙 과실을 말린 것으로 그 성질은 간(肝), 비(脾), 위(胃)에 귀경(歸經)하며(Yang et

Received: April 30, 2021 / Revised: June 9, 2021 / Accepted: June 14, 2021

* Graduate student, ${ }^{* *}$ Professor.

${ }^{\dagger}$ Corresponding author: Seong-Soo Roh. Department of Herbology, College of Korean Medicine, Daegu Haany University, 136, Sincheondong-ro, Suseong-gu, Daegu 42158, Korea.

Tel: +82-53-770-2350, Fax:+82-53-768-6340, e-mail: ddede@dhu.ac.kr

(C)The Korean Society for Biomedical Laboratory Sciences. All rights reserved.

(2) This is an Open Access article distributed under the terms of the Creative Commons Attribution Non-Commercial License (http://creativecommons.org/licenses/by-nc/3.0/) which permits unrestricted non-commercial use, distribution, and reproduction in any medium, provided the original work is properly cited. 
al., 2019; Kim et al., 2003), 한방에서는 주로 건위(健胃), 해 독(解毒) 등에 사용되어 왔다(Yun et al., 2008). 오수유의 주 요 성분으로는 evodiamine, rutaecarpine, evocarpine 등이 알 려져 있고(Yang et al., 2020), 약리 효능으로는 항산화(Yang et al., 2020), 항염증(Yun et al., 2008) 등의 효과가 알려져 있으며, 특히 이전 연구를 통해 오수유 물 추출물이 급성 및 만성 역류성 식도염에서 식도 점막을 보호한다는 연 구 결과가 밝혀졌다(Kim and Roh, 2012; Lee et al., 2019).

빈랑자(檳榔子; Arecae Serum)는 야자나무과(棕櫊科; Arecaceae/Palmae)에 속하는 빈랑나무의 열매이다(Lee et al., 2014). 빈랑자는 tannin, isoflavones 등의 성분을 포함하며, 한방에서는 주로 회충(蛔蟲), 복부팽창(腹部膨脹), 설사(泄 瀉), 소화불량(消化不良) 등에 사용되어 왔다(Lin et al., 2020). 약리 효능에 대한 연구로는 주로 위장운동성(Zhang et al., 2020; Zhnag et al., 2017)과 관련된 연구가 이루어졌으 며, 또한 급성 및 만성 역류성 식도염에서 식도 점막을 보호한다는 연구 결과가 밝혀졌다(Kim, 2019).

이에 본 연구에서는 급성 및 만성 역류성 식도염에 효 과가 있다고 알려진 오수유와 빈랑자을 혼합하여 그 혼 합물이 만성 역류성 식도염 동물에게 미치는 효과를 확인 하였다. 오수유와 빈랑자의 배합은 1:1 배합비 및 한방에 서 소화가 잘 되지 않아 나타나는 병증인 수곡리(水穀痢), 손설(飧泄)에 사용되는 배합인 $1: 5$ (오수유-빈랑자 $=1: 1$, 1:5) 배합비를 사용하였으며, 만성 역류성 식도염에 대한 오수유-빈랑자 혼합물의 효능 확인 결과, 유의한 결과를 얻었으며 이에 대하여 보고하는 바이다.

\section{재료 및 방법}

\section{재료}

시료: 본 실험에서 사용한 오수유와 빈랑자는 옹기한약국 (대구, 한국)에서 구입한 것을 생약규격집에 맞추어 관능 검사를 진행한 후 약전규격에 적합한 것만은 정산하여 사용하였다. 빈랑자와 오수유를 각각 $200 \mathrm{~g}$ 씩 분쇄하여 증류수 $2,000 \mathrm{~mL}$ 첨가한 후 열탕 추출기를 이용하여 2시 간 동안 추출하였다. 얻어진 추출물은 감압 추출장치로 농축하였으며, 동결 건조기를 이용해 건조시켜 파우더(오 수유; $15.66 \%$, 빈랑자; $6.75 \%$ )를 얻었다. 파우더는 $-80{ }^{\circ} \mathrm{C}$ 에 서 보관하였으며, 사용 직전 증류수에 녹여 사용하였다.

시약: 본 실험에 사용한 potassium phosphate monobasic, potassium phosphate dibasic, 2', 7'Dichlorofluorescein diace- tate (DCFH-DA)은 Sigma-Aldrich Co. (St. Louis, MO, USA) 에서 구입하여 사용하였다. Nitrocellulose membrane은 Amersham GE Healthcare (Little. Chalfont, UK)에서 구입하였 고, NADPH oxidase 2 (NOX2), p47 $7^{\text {phox }}$, phospho-p38 MAPK (p-p38), phosphorylation of nuclear factor-kappa B p65 (NF$\kappa B p 65)$, phosphorylation inhibitor of nuclear factor kappa $B$ alpha ( $\mathrm{p}-\mathrm{I} \kappa \mathrm{B} \alpha)$, inhibitor of nuclear factor kappa B alpha ( $\mathrm{I} \kappa \mathrm{B} \alpha)$, inducible nitric oxide synthase (iNOS), cyclooxygenase-1 (COX1), cyclooxygenase-2 (COX-2), Occludin, Claudin-1, Claudin-4, matrix metalloproteinase-2 (MMP-2), matrix metalloproteinase8 (MMP-8), tissue inhibitor of metalloproteinase-1 (TIMP-1), tissue inhibitor of metalloproteinase-2 (TIMP-2) Histone, $\beta$ actin은 Santa Cruz Biotechnology (Dallas, CA, USA)로부터 구입하였다. p38 MAPK (p38)는 Cell Signaling Technology, Inc. (Beverly, MA, USA)에서 구입하여 사용하였으며, 2차 항체는 GeneTex, Inc. (Irvine, LA, USA)에서 구입하여 사용 하였다. Protease inhibitor mixture, ethylenediaminetetraacetic acid (EDTA)는 Wako Pure Chemical Industries, Ltd. (Osaka Japan)에서 구입하였다. ECL western blotting detection reagents는 GE Healthcare 로부터 구입하여 사용하였으며, 단 백질 정량을 위한 BCA protein assay kit는 Thermo Scientific (Rockford, IL, USA)에서 구입하였다.

실험 동물: 5주령 수컷 Sprague-Dawley rat(대한바이오링 크, 음성, 한국)를 구입하여 1주일 동안 실험실 환경에 적 응시킨 후 실험을 진행하였다. 동물 사육실 조건은 conventional system으로 온도 $22 \pm 2{ }^{\circ} \mathrm{C}$, 습도 $50 \pm 5 \%$, 명암주 기(light: dark cycle)는 12시간 주기로 조절하였고, 사료(조 단백질 $18 \%$ 이상, 조회분 $8.0 \%$ 이하, 조섬유 $5.0 \%$ 이하, 조지방 $5.0 \%$ 이상, 칼슘 $1.0 \%$ 이상, 인 $0.85 \%$ 이상, 칼륨 $0.55 \%$ 이상, 나트륨 $0.25 \%$ 이상, 마그네슘 $0.15 \%$ 이상, NIH-41, Zeigler Bros, Inc., Gardners, PA, USA)와 물은 충분 히 공급하였다. 본 연구는 동물실험의 과학적, 윤리적 타 당성 검토 및 효율적인 관리를 위하여 대구한의대학교 동물실험윤리 위원회(Institutional Animal Care and Use Committee: IACUC)의 승인(승인번호: DHU2021-026)을 받 아 진행되었다.

\section{방법}

만성 역류성 식도염 유발 및 동물 처치: 18시간 절식 후, Zoletil (Vibrac, France)을 복강주사하여 마취시켰으며, 역류 성 식도염 유발을 위한 수술을 진행하였다. 제모기로 복 
부털을 제거하여 복간 정중부를 $2 \mathrm{~cm}$ 정도 개복하여 위 저부(Fundus)를 블랙 실크(2-0)실로 묶고, 유문부(pylorus) 에는 latex ring (18-Fr Nelaton catheter, $2 \mathrm{~mm}$ in thickness)을 끼워 latex ring이 풀리지 않도록 나일론(5-0)실로 묶은 후 복막과 피부를 봉합하였다(Omura et al., 1999). 감염을 줄이 기 위해 3일간 항염증제(Dexamethasone)와 항생제(Gentamicin sulfate)를 희석하여 피하주사 하였으며, 수술 24시간 후 물을 공급해주었고, 수술 48시간 후부터 사료를 공급 해 주었다. 1 주일간 회복기를 거친 후, 아무런 처치를 하 지 않은 정상군(Normal), 만성 역류성 식도염 유발 후 증 류수를 투여한 대조군(Control), 만성 역류성 식도염 유 발 후 오수유-빈랑자(1:1) 혼합물 $200 \mathrm{mg} / \mathrm{kg}$ 를 투여한 군 (EA1), 만성 역류성 식도염 유발 후 오수유-빈랑자(1:5) 혼합물 $200 \mathrm{mg} / \mathrm{kg}$ 를 투여한 군(EA5) 총 4그룹으로 무작위 분류하였으며, 모든 그룹은 매일 일정한 시간에 몸무게 및 사료 섭취량을 측정하였고, 14 일간 1 일 1 회씩 경구투 여 하였다.

식도 손상 면적 측정: 수술용 가위를 이용하여 적출한 식 도를 세로로 절단하였다. 절단된 식도 내부를 saline으로 세척한 후 고정하여 광학 디지털 카메라(DSCHX50V, Sony, Tokyo, Japan)를 이용하여 촬영하였다. 손상된 식도 점막 측정은 I-Solution lite (Innerview Co., Seongnam, Korea) 프 로그램을 이용하여 실제 손상 부위의 면적을 측정한 후, 아래 식을 이용하여 손상 면적을 나타내었다.

$$
\text { 식도 손상 비율 }=\frac{\text { 식도 손상 면적 }}{\text { 식도 전체 면적 }} \times 100
$$

혈액분석: 복대정맥에서 채혈한 혈액에서 혈청을 분리하 여 GOT (Glutamic oxaloacetic transaminase), GPT (Glutamic pyruvic transaminase) 및 MPO (Myeloperoxidase) level을 측정하였다. GOT, GPT(아산제약, 서울, 한국) 및 $\mathrm{MPO}$ (Biovision, Inc., CA, USA)는 시약세트를 구입하여 측정하 였다.

식도 조직 western blotting: 식도 조직의 세포질을 얻기 위해 1.5 M sucrose, 0.1 M DTT, $100 \mathrm{mM}$ Tris- $\mathrm{HCl}$ (pH 7.4), $15 \mathrm{mM} \mathrm{CaCl}_{2}, 5 \mathrm{mM}$ Tris- $\mathrm{HCl}$ (pH 7.5), $2 \mathrm{mM} \mathrm{MgCl}_{2}$, protease inhibitor cocktail을 첨가한 buffer $\mathrm{A}$ 를 넣고 조직 분쇄기 (tissue grinder) (Biospec Product, Bartlesville, OK, USA)로 분 쇄한 후 $10 \% \mathrm{NP}-40$ 을 첨가하여 아이스 위에서 30 분간 정
치하였으며, 원심분리 $\left(12,000 \mathrm{rpm}, 4{ }^{\circ} \mathrm{C}, 2\right.$ 분 $)$ 하여 세포질을 포함하고 있는 상층액을 분리하였다. 핵을 얻기 위해 $10 \%$ $\mathrm{NP}-40$ 가 더해진 buffer $\mathrm{A}$ 에 두 번 헹구고 $100 \mu \mathrm{L}$ 의 buffer C (50 mM HEPES, $50 \mathrm{mM} \mathrm{KCl,} 1 \mathrm{mM}$ DTT, $0.3 \mathrm{mM} \mathrm{NaCl}$, $0.1 \mathrm{mM}$ EDTA, $0.1 \mathrm{mM}$ PMSF, $10 \%$ glycerol)를 첨가해 재부 유시킨 후 10 분마다 vortex를 3 번 하였다. 그 후 원심분리 $\left(12,000 \mathrm{mpm}, 4^{\circ} \mathrm{C}, 10\right.$ 분)하여 핵을 포함하고 있는 상층액을 얻어 $-80^{\circ} \mathrm{C}$ 에서 각각 냉동 보관하였다. 식도 조직 세포질 의 NOX2, p47 $7^{\text {phox }}, \mathrm{p}-\mathrm{p} 38, \mathrm{p} 38, \mathrm{p}-\mathrm{I} \kappa \mathrm{B} \alpha, \mathrm{I} \kappa \mathrm{B} \alpha$, iNOS, COX-1, COX-2, Occludin, Claudin-1, Claudin-4, MMP-2, MMP-8, TIMP-1, TIMP-2, $\beta$-actin 단백질과 핵에서의 NF- $\kappa \mathrm{Bp} 65$, histone 단백질 발현을 측정하기 위하여 $12 \mu \mathrm{g}$ 의 단백질을 $10 \sim 12 \%$ SDS polyacrylamide gel을 이용하여 전기영동 후, acrylamide gel을 nitrocellulose membrane으로 이동시켰다. 준비된 membrane에 각각의 1차 antibody (1:1,000)를 처리 하여 $4^{\circ} \mathrm{C}$ 에서 overnight 시킨 다음 PBS-T로 6 분마다 5 회 세척하고, 각각 처리된 1차 antibody에 사용되는 2차 antibody $(1: 3,000)$ 를 사용하여 상온에서 2 시간 반응시킨 후, PBS-T로 6분마다 5회 세척하였다. 단백질 발현을 확인하 기 위하여 membrane을 enhanced chemiluminescence (ECL) 용액에 노출시킨 후, Sensi-Q2000 Chemidoc (Lugen Sci Co., Ltd., Seoul, Korea)에 감광시켜 단백질 발현을 확인한 후, 해당 band를 ATTO Densitograph Software (ATTO Corporation, Tokyo, Japan) 프로그램을 사용하여 정량하였다.

통계분석: In vivo의 수치는 mean $\pm \mathrm{SD}$ 로 표시하였으며, SPSS (Version 25.0, IBM, Armonk, NY, USA)를 사용하여 one-way analysis of variance (ANOVA) test를 실시한 후 least-significant differences (LSD) test로 사후검증을 실시하 여 각 군의 평균 차이에 대한 통계적 유의성을 $* P<0.05$, ** $P<0.01, * * * P<0.001$ 에서 검증하였다.

\section{결 과}

\section{식도 손상 면적 측정}

식도 점막의 손상을 확인한 결과, 아무런 처치를 하 지 않은 Normal군 $(0.58 \pm 0.26 \%)$ 에서는 식도 점막의 손 상 및 궤양이 확인되지 않았으나 Control군 $(7.74 \pm 2.43 \%$; $P<0.001)$ 에서는 식도 중앙부에서 큰 궤양이 발견되었으며, 하부식도에서 또한 궤양을 확인할 수 있었다. 반면, Control군에 비하여 $\mathrm{EA} 1$ 군에서 $60 \%(P<0.001), \mathrm{EA} 5$ 군에서 $47 \%(P<0.01)$ 식도 손상이 유의하게 감소한 것을 확인하 
A
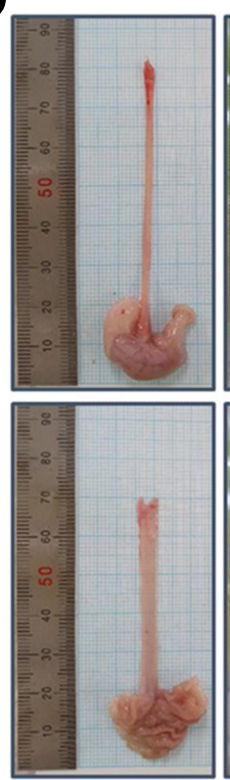

Normal
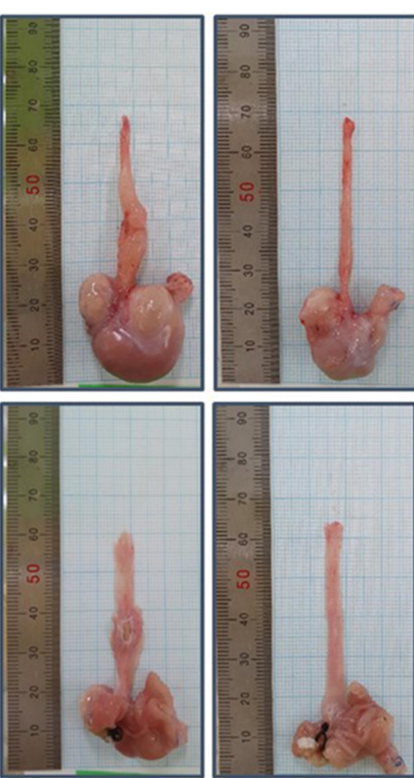

Control

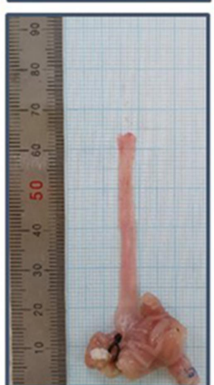

EA1
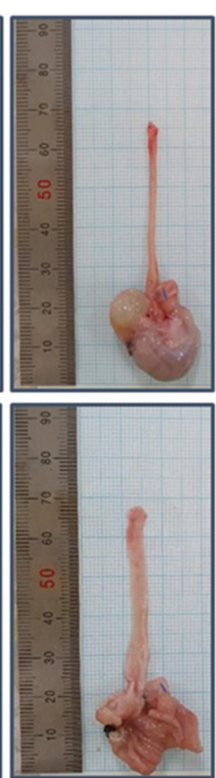

EA5
B

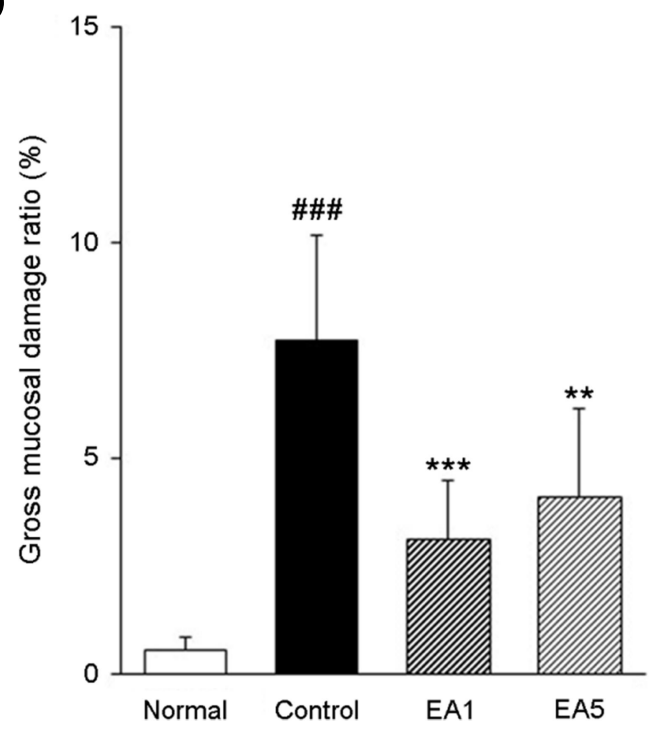

Fig. 1. Surgical induction of chronic acid reflux esophagitis. A representative gross image; (A), esophageal ulcer ratio; (B). Normal group; Normal, chronic acid reflux esophagitis rats; Control, mixture of Evodiae Fructus and Arecae Semen in 1:1 ratio $200 \mathrm{mg} / \mathrm{kg}$-treated chronic acid reflux esophagitis rats; EA1, mixture of Evodiae Fructus and Arecae Semen in 1:5 ratio $200 \mathrm{mg} / \mathrm{kg}$-treated chronic acid reflux esophagitis rats; EA5. Significance: \#\#P<0.001 vs. Normal group, ${ }^{* *} P<0.01,{ }^{* * *} P<0.001$ vs. Control group.

Table 1. Levels of GOT, GPT, and MPO in Serum

\begin{tabular}{llcc}
\hline \hline & GOT (IU/L) & GPT (IU/L) & MPO (mU/mL) \\
\hline Normal & $32.89 \pm 2.90$ & $6.11 \pm 0.62$ & $0.53 \pm 0.07$ \\
Control & $51.50 \pm 2.08^{\# \#}$ & $11.52 \pm 0.34^{\# \#}$ & $0.90 \pm 0.10^{\# \#}$ \\
EA1 & $38.26 \pm 1.63^{* * *}$ & $6.00 \pm 0.46^{* * *}$ & $0.56 \pm 0.11^{*}$ \\
EA5 & $43.24 \pm 1.16^{* *}$ & $8.28 \pm 0.42^{* * *}$ & $0.63 \pm 0.07^{*}$ \\
\hline
\end{tabular}

GOT; Glutamic oxaloacetic transaminase, GPT; Glutamic pyruvic transaminase, MPO; Myeloperoxidase. All date are expressed mean $\pm \mathrm{SD}(\mathrm{n}=8)$. Normal group; Normal, chronic acid reflux esophagitis rats; Control, mixture of Evodiae Fructus and Arecae in 1:1 ratio $200 \mathrm{mg} / \mathrm{kg}$-treated chronic acid reflux esophagitis rats; EA1, mixture of Evodiae Fructus and Arecae in 1:5 ratio $200 \mathrm{mg} / \mathrm{kg}-$ treated chronic acid reflux esophagitis rats; EA5. Significance: ${ }^{\#} P<0.01,{ }^{\# \#} P<0.001$ vs. Normal group, ${ }^{*} P<0.05,{ }^{* *} P<0.01,{ }^{* * *} P<$ 0.001 vs. Control group

였다(Fig. 1).

\section{GOT, GPT 및 MPO 측정}

GOT 및 GPT 수치 확인 결과, Normal군 대비 Control군 $(P<0.001)$ 에서 유의하게 증가하였으며, 특히 GPT의 수치 가 Normal군 대비 Control군에서 약 2배 크게 증가하였다. 반면, Control군 대비 $\mathrm{EA} 1$ 군 $(P<0.001)$ 에서는 유의하게 감
소하여 Normal군과 비슷한 수치를 나타냈으며, EA5군에 서 또한 $\mathrm{GOT}(P<0.01)$, GPT $(P<0.001)$ 모두 유의하게 감 소하였다. $\mathrm{MPO}$ 측정 결과, Normal군 대비 Control군에서 $69 \%(P<0.01)$ 유의하게 증가하였으며, Control군 대비 EA1 군에서 $38 \%(P<0.05)$ 유의하게 감소하여 Normal군과 비슷 한 수치를 나타냈으며, EA5군 또한 $30 \%(P<0.05)$ 유의하 게 감소하였다(Table 1).

\section{간 조직 western blotting}

NADPH oxidase/iNOS 발현량 분석: 식도 조직 내 $\mathrm{NADPH}$ oxidase의 발현량을 분석한 결과, Normal군 대비 Control군에서 NOX2 $33 \%, \mathrm{p} 47^{\mathrm{phox}} 21 \%$ 유의하게 증가하 였으며, Control군 대비 EA1군은 NOX2와 p47 $7^{\text {phox }}$ 모두 약 $50 \%$ 유의하게 감소하였으며, EA5군에서 또한 $\mathrm{NOX} 2$, $\mathrm{p} 47^{\mathrm{phox}}$ 모두 약 $40 \%$ 유의하게 감소하였다. 또한, iNOS의 발현은 Normal군 대비 Control군에서 $41 \%$ 유의하게 증가 하였으며, Control군 대비 EA1군 $41 \%$, EA5군 $27 \%$ 유의 하게 감소하여 EA1과 EA5군 모두 Normal군과 비슷한 수 치까지 감소하였다(Fig. 2).

염증 전사인자 발현량 분석: 식도 조직 내 염증 전사인 

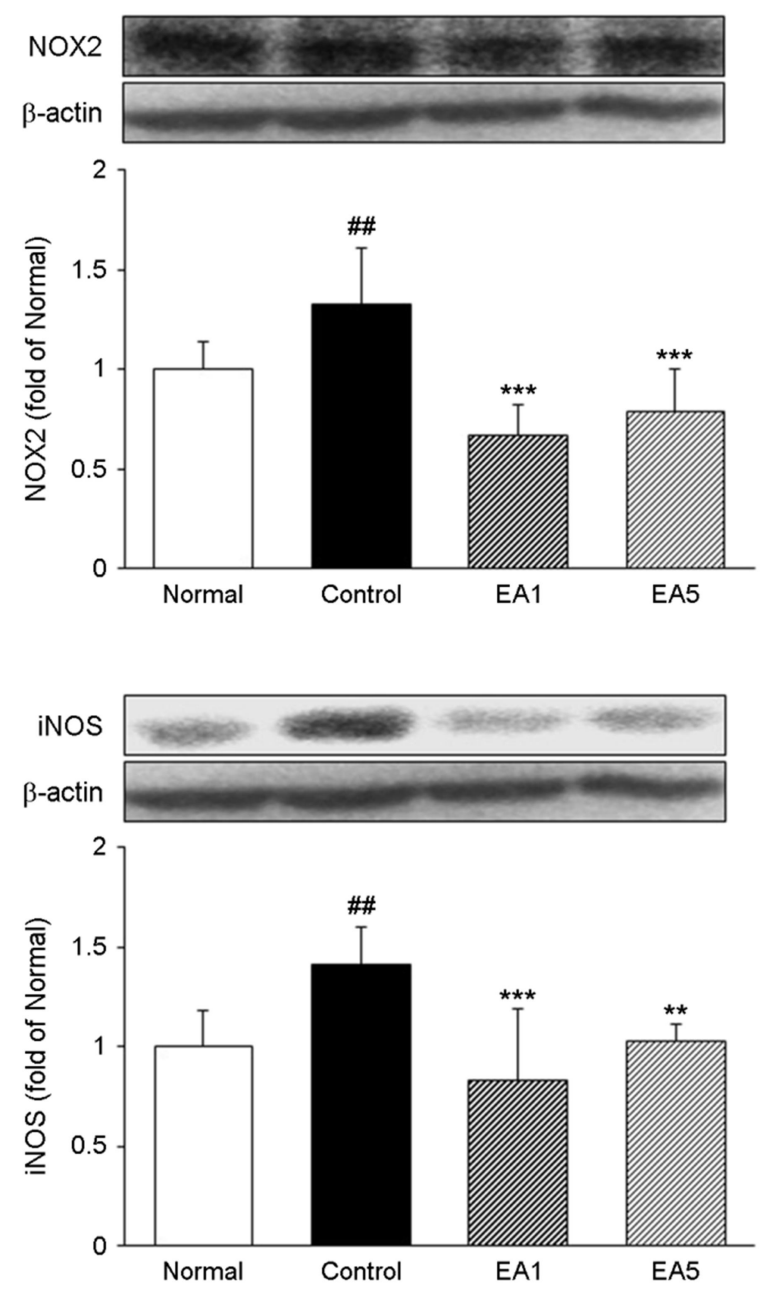

자 p-p38, NF-kBp65, p-I $\mathrm{KB} \alpha$ 의 발현을 확인한 결과, $\mathrm{p}-\mathrm{p} 38$ 의 발현량은 Normal군 대비 Control군에서 2배 이상 유의 하게 증가하였으며, Control군 대비 EA1군과 EA5군 모두 $36 \%$ 유의하게 감소하였다. 또한, Normal군 대비 Control군 에서 NF-kBp65의 발현은 $82 \%$ 유의하게 증가하였으며, $\mathrm{p}-\mathrm{I} \kappa \mathrm{B} \alpha$ 의 발현은 $56 \%$ 유의하게 증가하였다. 반면, Control 군 대비 $\mathrm{EA} 1$ 군에서 NF-kBp65의 발현량이 $37 \%$ 유의하게 감소하였으며, EA5군에서 NF- $\mathrm{KBp} 65$ 와 $\mathrm{p}-\mathrm{I} \kappa \mathrm{B} \alpha$ 의 발현량의 약 $30 \%$ 유의하게 감소하였다(Fig. 3).

Arachidonic acid 관련 인자 발현량 분석: 식도 조직 내 arachidonic acid 관련 인자인 COX-1 및 COX-2의 발현을 확인한 결과, Normal군 대비 Control군에서 COX-1은 $54 \%$ 유의하게 감소하였으며, $\mathrm{COX}-2$ 는 $50 \%$ 유의하게 증가하 였다. 반면, $\mathrm{COX}-1$ 의 발현은 Control군 대비 EA1군에서 $53 \%, \mathrm{EA} 5$ 군에서 $68 \%$ 유의하게 증가하였으며, $\mathrm{COX}-2$ 의

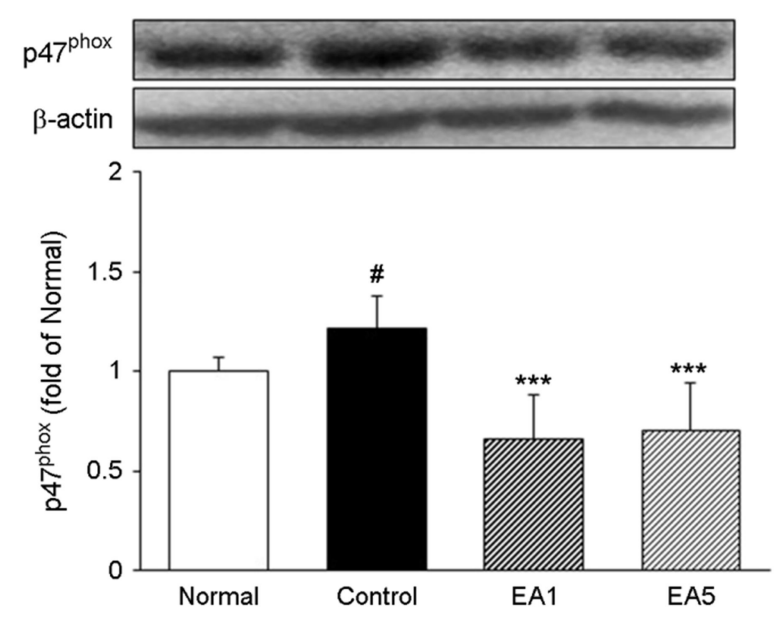

Fig. 2. Expression of NADPH oxidase and iNOS in esophagus. All date are expressed mean $\pm \mathrm{SD}(\mathrm{n}=8)$. Normal group; Normal, chronic acid reflux esophagitis rats; Control, mixture of Evodiae Fructus and Arecae Semen in 1:1 ratio $200 \mathrm{mg} / \mathrm{kg}-$ treated chronic acid reflux esophagitis rats; EA1, mixture of Evodiae Fructus and Arecae Semen in 1:5 ratio $200 \mathrm{mg} / \mathrm{kg}$ treated chronic acid reflux esophagitis rats; EA5. Significance: $\# P<0.05, \# \# P<0.01$ vs. Normal group, $* * P<0.01, * * * P<0.001$ vs. Control group.

발현은 Control군 대비 EA1군 $43 \%$, EA5군 $32 \%$ 유의하게 감소하였다(Fig. 4).

Tight junction 발현량 분석: 식도 조직 내에서 tight junction 단백질인 Occludin, Claudin-1 및 Claudin-4의 발현 을 확인한 결과, Claudin-1의 발현은 Normal군 대비 Control군에서 $59 \%$ 유의하게 감소하였으며, Control군 대비 $\mathrm{EA} 1$ 군과 $\mathrm{EA} 5$ 군에서 $60 \%$ 유의하게 증가하였다. 또한, Normal군 대비 Control군에서 Occludin과 Claudin-4의 발현 이 $48 \%$ 유의하게 감소하였으며, Control군 대비 EA1군과 EA5군에서 Occludin과 Claudin- 4 의 발현이 약 $40 \%$ 유의하 게 증가하였다(Fig. 5).

MMPs/TIMPs 발현량 분석: 식도 조직 내에서 MMP-2, MMP-8, TIMP-1 및 TIMP-2의 발현을 확인한 결과, Normal 군 대비 Control군에서 MMP-2의 발현이 $39 \%$ 유의하게 

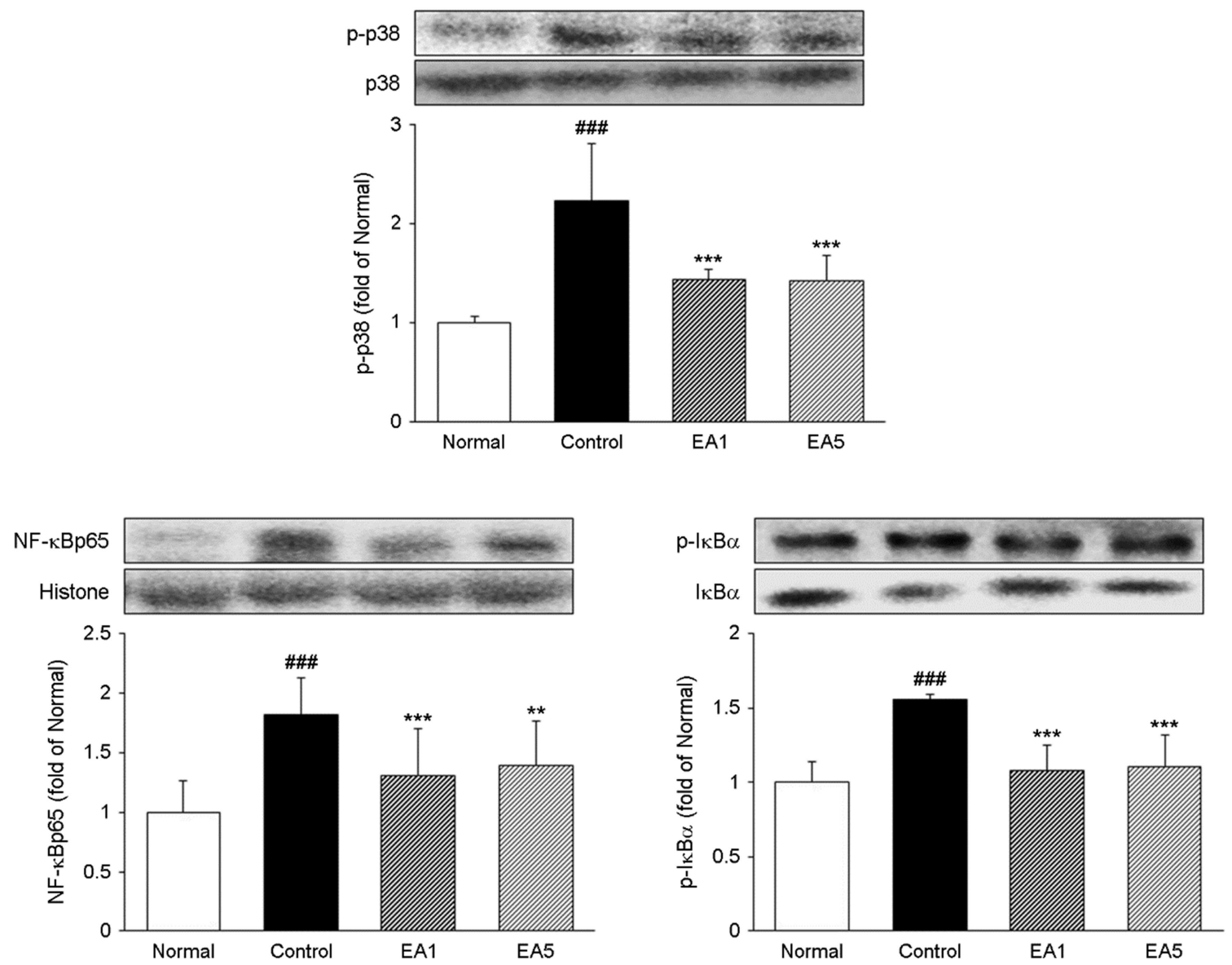

Fig. 3. Expression of inflammatory transcription factors in esophagus. All date are expressed mean \pm SD ( $n=8)$. Normal group; Normal, chronic acid reflux esophagitis rats; Control, mixture of Evodiae Fructus and Arecae Semen in 1:1 ratio $200 \mathrm{mg} / \mathrm{kg}$-treated chronic acid reflux esophagitis rats; EA1, mixture of Evodiae Fructus and Arecae Semen in 1:5 ratio $200 \mathrm{mg} / \mathrm{kg}$-treated chronic acid reflux esophagitis rats; EA5. Significance: \#\#P<0.001 vs. Normal group, ${ }^{* *} P<0.01$, $* * * P<0.001$ vs. Control group.
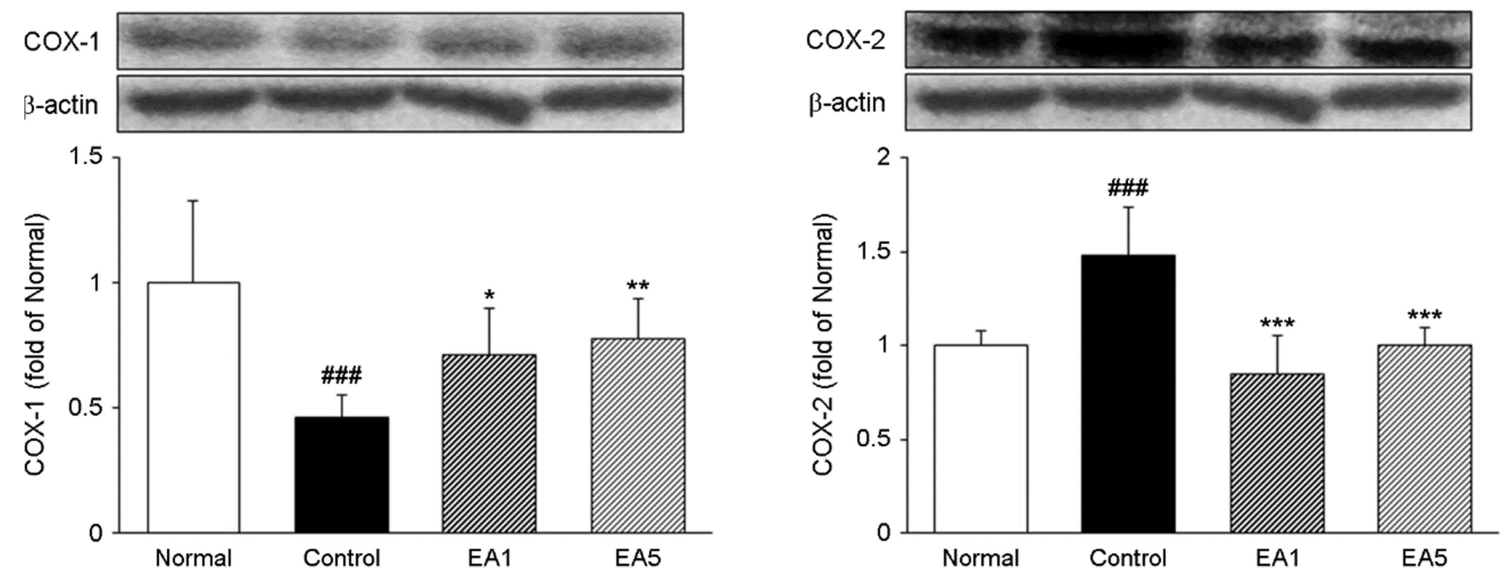

Fig. 4. Expression of arachidonic acid proteins in esophagus. All date are expressed mean $\pm S D(n=8)$. Normal group; Normal, chronic acid reflux esophagitis rats; Control, mixture of Evodiae Fructus and Arecae Semen in 1:1 ratio $200 \mathrm{mg} / \mathrm{kg}$-treated chronic acid reflux esophagitis rats; EA1, mixture of Evodiae Fructus and Arecae Semen in 1:5 ratio $200 \mathrm{mg} / \mathrm{kg}$-treated chronic acid reflux esophagitis rats; EA5. Significance: \#\#\#P<0.001 vs. Normal group, ${ }^{*} P<0.05$, $* * P<0.01, * * * P<0.001$ vs. Control group. 

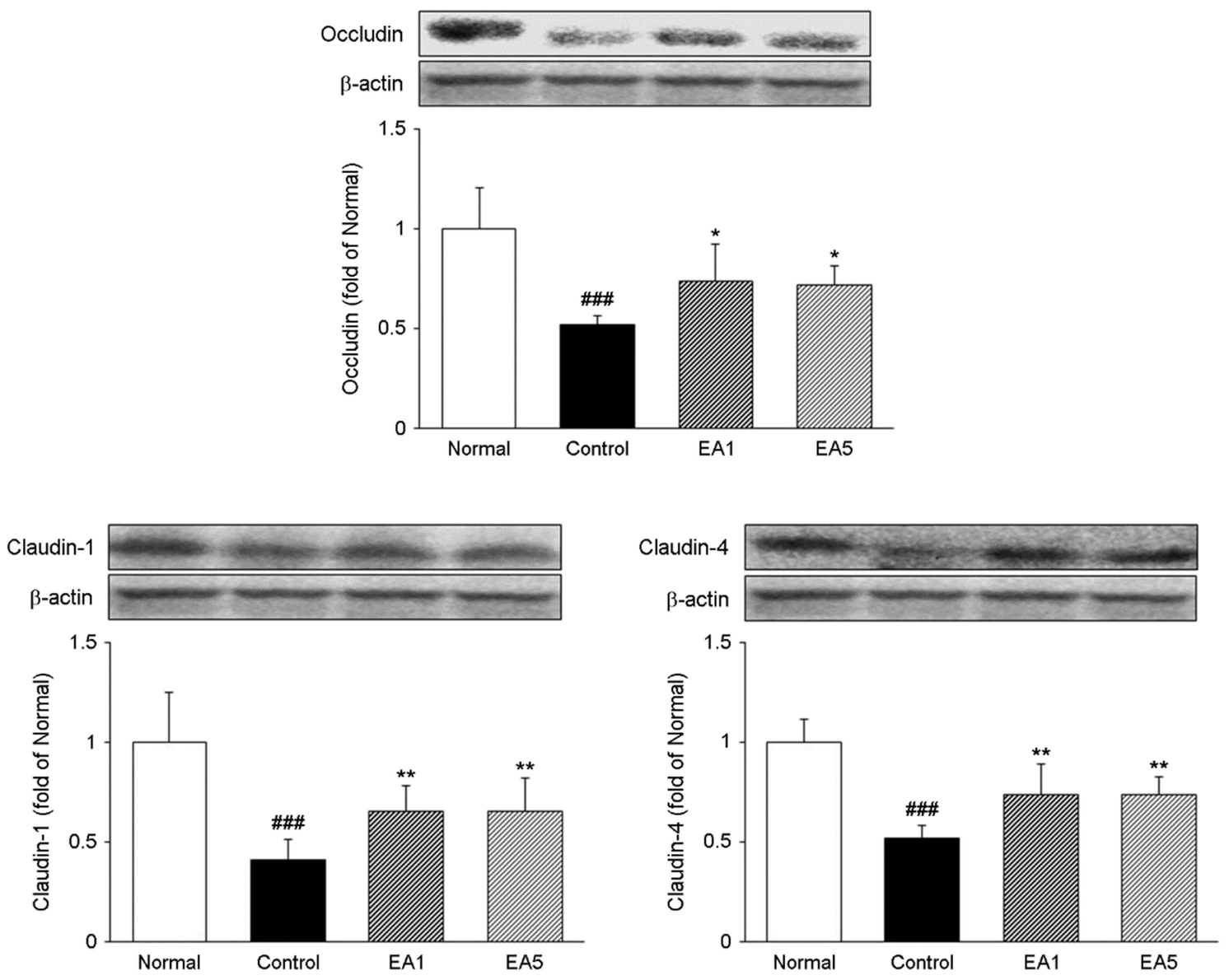

Fig. 5. Expression of tight junction proteins in esophagus. All date are expressed mean $\pm S D(n=8)$. Normal group; Normal, chronic acid reflux esophagitis rats; Control, mixture of Evodiae Fructus and Arecae Semen in 1:1 ratio $200 \mathrm{mg} / \mathrm{kg}$-treated chronic acid reflux esophagitis rats; EA1, mixture of Evodiae Fructus and Arecae Semen in 1:5 ratio $200 \mathrm{mg} / \mathrm{kg}$-treated chronic acid reflux esophagitis rats; EA5. Significance: \#\# $\#<0.001$ vs. Normal group, ${ }^{*} P<0.05$, ${ }^{*} P<0.01$ vs. Control group.

증가한 반면 Control군 대비 EA1군, EA5군 모두 $41 \%$ 유 의하게 감소하였다. 또한, MMP-8의 발현은 Normal군 대 비 Control군에서 $50 \%$ 유의하게 증가하였으며, Control군 대비 $\mathrm{EA} 1$ 군에서 $33 \%$, EA5군에서 $28 \%$ 유의하게 감소하 였다. TIMP-1과 TIMP-2의 발현은 Normal군 대비 Control 군에서 $41 \%$ 유의하게 감소하였으며, Control군 대비 EA1 군에서 $30 \%$ 이상 유의하게 증가하였고, $\mathrm{EA} 5$ 군에서 $35 \%$ 이상 유의하게 증가하였다(Fig. 6).

\section{고 찰}

역류성 식도염(Reflux esophagitis)은 일반적으로 위액의 역류로 인해 염증이 생겨 식도 조직의 출혈, 점막 궤양 및 괴사가 일어나는 질환으로써 역류성 식도염의 원인은
다양하지만 일반적으로 하부식도 괄약근(lower esophageal spincter; LES)의 압력이 낮아 부적절하게 이완되어 발생하 는 것으로 알려져 있다(Shin et al., 2016). 1990년대까지만 하더라도 우리나라를 포함한 아시아 국가에서는 역류성 식도염의 유병율이 낮게 나타났기 때문에 관심을 가지던 질환이 아니였으나 2000년대에 들어서면서 유병율이 지 속적으로 증가함으로써 역류성 식도염에 대한 관심과 다 양한 연구가 증가하고 있는 추세이다(Cho et al., 2005). 이 에 본 연구에서는 급성 및 만성 역류성 식도염에 대하여 식도 점막 보호 효과가 있다고 알려진 오수유와 빈랑자 를 배합하였으며, 그 혼합물이 식도 점막에 미치는 효과 를 알아보고자 하였다(Kim and Roh, 2012; Kim, 2019; Lee et al., 2019). 오수유와 빈랑자의 배합은 1:1 배합비 및 한 방에서 소화가 잘 되지 않아 나타나는 병증인 수곡리(水 

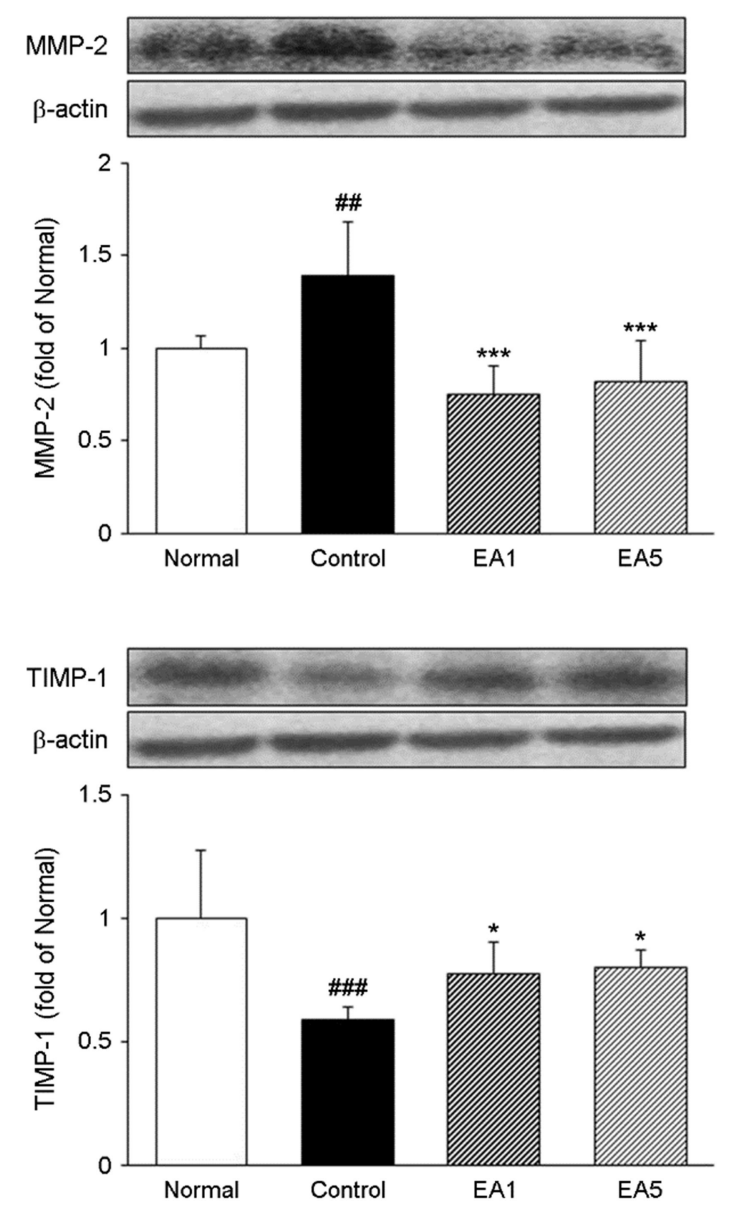
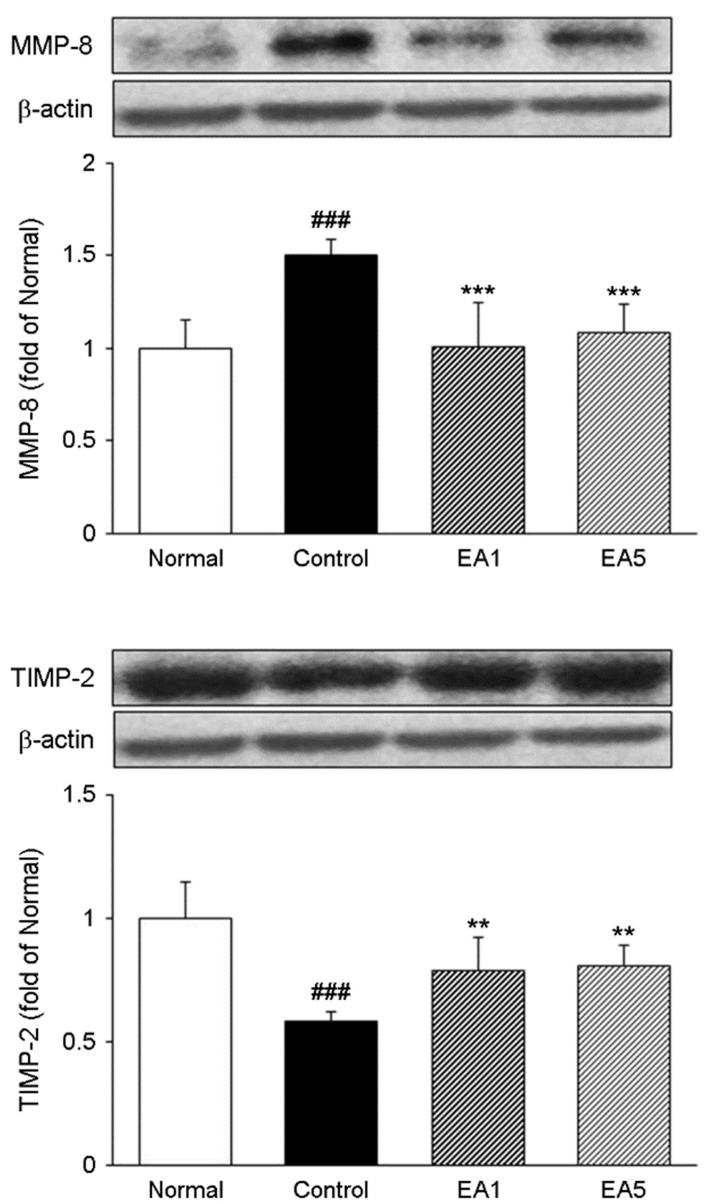

Fig. 6. Expression of MMP/TIMP proteins in esophagus. All date are expressed mean $\pm \mathrm{SD}(\mathrm{n}=8)$. Normal group; Normal, chronic acid reflux esophagitis rats; Control, mixture of Evodiae Fructus and Arecae Semen in 1:1 ratio $200 \mathrm{mg} / \mathrm{kg}$-treated chronic acid reflux esophagitis rats; EA1, mixture of Evodiae Fructus and Arecae Semen in 1:5 ratio $200 \mathrm{mg} / \mathrm{kg}$-treated chronic acid reflux esophagitis rats; EA5. Significance: ${ }^{\#} P<0.01,{ }^{\#} P<0.001$ vs. Normal group, ${ }^{*} P<0.05,{ }^{* *} P<0.01,{ }^{* * *} P<0.001$ vs. Control group.

穀痢), 손설(飧泄)에 사용되는 배합인 1:5(오수유-빈랑자 $=1: 1,1: 5)$ 배합비를 사용하였다.

먼저, 18시간 절식 후 수술을 통해 $\mathrm{SD}$ rat에게 역류성 식도염을 유발하였으며, 1 주일 동안 적응 기간을 거친 후, 2주간 오수유-빈랑자 1:1 혼합물(EA1)과 1:5 혼합물(EA5) 을 경구투여하여 식도 조직을 적출하였다. 적출한 식도 조직의 손상 면적을 확인한 결과, 아무런 처치를 하지 않은 Normal군에서는 식도 점막의 손상 및 궤양이 확인 되지 않았으나 Control군에서는 식도 중앙부에서 큰 궤양 이 발견되었으며, 하부식도에서 또한 궤양을 확인할 수 있었으며, Control군에 비하여 EA1군에서 $60 \%$, EA5군에 서 $47 \%$ 식도 점막의 손상이 유의하게 개선된 것을 확인 하였다(Fig. 1).

그 후, 혈액에서 분리한 혈청을 이용하여 GOT, GPT 및
$\mathrm{MPO}$ 의 수치를 확인하였다. 간세포가 손상되면 GOT 및 $\mathrm{GPT}$ 와 같은 효소들이 혈중으로 흘러나와 혈중 GOT, GPT 농도가 상승한다(Fitzhugh and Nelson, 1948). 본 연구에서 사용한 빈랑자는 많은 연구를 통해 독성이 있는 것으로 알려져 있어 남용할 경우 심각한 부작용이 나타나는 것 으로 알려져 있다(Roh and Seo, 2012). 이에 본 연구에서는 빈랑자의 독성으로 인한 동물의 간 손상 유무를 확인하기 위하여 혈중 GOT 및 GPT의 수치를 확인한 결과, 스트레 스 및 만성 역류성 식도염 수술 과정에서 GOT와 GPT 수치가 EA1군에서 유의하게 감소하여 Normal군과 비슷 한 수치를 나타냈으며, EA5군에서 또한 GOT, GPT 모두 유의하게 감소하였다(Table 1).

MPO (myeloperoxidase)는 면역 체계의 핵심 요소이며, 상처 및 감염부위에서 병원체에 대한 방어를 위하여 호 
중구로부터 방출되어 감염의 치료에 도움을 준다(Davies and Hawkins, 2020; Khan et al., 2018). 또한, MPO는 $\mathrm{H}_{2} \mathrm{O}_{2}$ 와 chloride ions $\left(\mathrm{Cl}^{-}\right)$를 촉매하여 hypochlorous acid $(\mathrm{HOCl})$ 를 형성시켜 산화적 손상 및 세포 기능 장애를 촉진할 뿐 아 니라 질병의 발병 및 만성 염증을 유발한다고 알려져 있 다(Daives and Hawkins, 2020). 산화적 스트레스(oxidative stress; OS)는 외부의 여러 자극에 의해 NADPH oxidase (NOX)로부터 발생된 활성산소종(reactive oxygen species; $\mathrm{ROS}$ )에 의해 생성되어 염증뿐 아니라 다양한 질병의 유 발과 밀접한 관련이 있는 것으로 알려져 있다. OS를 발생 시키는 또 다른 요소 중 하나인 질소종 $(\mathrm{NO})$ 또한 과잉 생산될 경우 세포의 산화 및 손상에 관여하여 염증을 유 발하는 기초적인 기전이 된다고 알려져 있다(Kim and Son, 2006). 본 실험에서 EA1 투여는 만성 역류성 식도염에 의 해 증가한 혈중 $\mathrm{MPO}$ 수치 및 NADPH oxidase와 iNOS의 발현을 Normal군과 비슷한 수치까지 유의적으로 감소시 켰으며, EA5 투여 또한 $\mathrm{MPO}$ 수치 및 $\mathrm{NADPH}$ oxidase와 iNOS의 발현을 유의하게 감소시켰다(Table 1, Fig. 2). 이러 한 결과는 오수유-빈랑자 혼합물이 산화적 스트레스를 감소시킴으로써 식도 점막의 염증 완화에 관여할 것이라 판단된다.

$\mathrm{NF}-\kappa \mathrm{B}$ 는 인간의 면역 및 염증 반응에서 중요한 역할을 한다고 알려져 있는 전사인자로써 주로 NF- $\mathrm{NB}$ 의 억제제 인 $\mathrm{I} \kappa \mathrm{B} \alpha$ 와 결합하여 세포질에 존재하다가 여러 병원체들 에 의해 $\mathrm{I} \kappa \mathrm{B} \alpha$ 가 인산화되면서 핵 안으로 이동해 DNA와 결합하여 COX-2, iNOS와 같은 타깃 유전자의 발현을 자 극함으로써 질병을 유발시키며, MAPK family 중 하나인 $\mathrm{p} 38$ 또한 NF- $\mathrm{NB}$ 의 활성화에 관여하여 NF- $\mathrm{NB}$ 의 염증 반 응을 돕는 것으로 알려져 있다(Youn, 2012; Chien et al., 2018). 식도 조직 내 염증 전사인자 p-p38, NF-кBp65, p$\mathrm{I} \kappa \mathrm{B} \alpha$ 의 발현을 확인한 결과, EA1과 EA5 투여는 p-p38, $\mathrm{NF}-\kappa \mathrm{Bp} 65, \mathrm{p}-\mathrm{I} \kappa \mathrm{B} \alpha$ 의 발현을 유의적으로 감소시킨 것을 확 인하였다(Fig. 3).

Cyclooxygenase (COX)는 아라키돈산(arachidonic acid)을 프로스타글란딘(prostaglandin)으로 변환시키는 역할을 하 며, COX-1과 COX-2의 형태로 존재한다(Vane et al., 1998). $\mathrm{NF}-\kappa \mathrm{B}$ 의 활성화로 인해 발현되는 $\mathrm{COX}-2$ 는 염증 반응에 관여하는 인자로 알려져 있으며, 염증 조직, 악성종양 등 에서 정상세포에 비해 많은 양의 프로스타글란딘을 생성 하여 세포의 증식을 도울 뿐 아니라 암세포의 성장에 적 합한 환경을 제공한다(Cho et al., 2015). 반면, COX-2 억제 제로 잘 알려져 있는 $\mathrm{COX}-1$ 은 위 및 혈소판에 존재하며,
위산을 조절할 뿐 아니라 위 점막을 보호하여 소화기계가 정상적인 기능의 유지를 돕는 중요한 역할을 한다(Foye and Lemke, 2008; Bhagavan, 2002). 식도 조직 내 arachidonic acid 관련 인자인 COX-1 및 $\mathrm{COX}-2$ 의 발현을 확인한 결 과, EA1과 EA5 투여는 식도 조직 내 $\mathrm{COX}-1$ 및 $\mathrm{COX}-2$ 의 발현을 유의적으로 조절하였다(Fig. 4). 이러한 결과는 오 수유-빈랑자 혼합물이 NF-kBp65의 활성화를 억제시킴으 로써 $\mathrm{COX}-1$ 과 $\mathrm{COX}-2$ 의 발현을 조절하는 것으로 판단 된다.

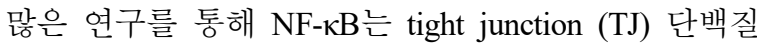
및 matrix metalloproteinases (MMPs)의 발현을 조절하는 것 으로 알려졌다(Shin and Choi, 2013). TJ 단백질은 표피와 세포층의 세포 간격에 위치하여 세포-세포간 수분, 전해 질 등의 이동을 조절하는 장벽 단백질이다. $\mathrm{TJ}$ 단백질에 는 Occludin, Claudin 등이 있으며(Kim and Jang, 2015), 역류 성 식도염이 유발되면 식도 점막의 손상으로 인해 결합 조직에서의 $\mathrm{TJ}$ 이 감소하는 것으로 알려져 있다(Lee et al., 2020). 또한 MMPs는 단백질분해효소로써 tissue inhibitor of metalloproteinases(TIMPs)에 의해 조절되며, TIMPs와 함께 신체의 결합 조직의 항상성을 유지시켜주는 것으로 알려 져 있으나 MMPs/TIMPs의 균형이 붕괴되면 세포외기질의 분해를 유도한다(Lee et al., 2020). 본 실험에서는 오수유빈랑자 혼합물을 투여하였을 때 tight junction 단백질의 발 현이 유의적으로 증가하였으며, MMPs의 발현이 Normal 군과 비슷한 수준까지 감소하였을 뿐 아니라 TIMPs의 발현이 유의적으로 증가하였다. 이러한 결과는 오수유빈랑자 혼합물이 상피세포의 결합 조직을 보호하였음을 나타낸다.

이상의 결과는 만성 역류성 식도염에서 오수유-빈랑자 혼합물은 산화적 스트레스 조절을 통해 NF- $\mathrm{BB}$ 경로를 억 제하였을 뿐 아니라 세포의 결합 조직에서 중요한 역할 을 하는 tight junction과 MMPs/TIMPs를 조절함으로써 식 도 점막의 손상을 완화한 것으로 판단되며, 이러한 효과 는 오수유-빈랑자 1:1 혼합물(EA1)에서 더욱 뛰어나게 나타났다.

\section{ACKNOWLEDGEMENT}

This work has supported by the National Research Foundation of Korea (NRF) grant funded by the Korea government (MSIT) (No. 2019R1I1A1A01064068 and No. 2017R1A2B2006858). 


\section{CONFLICT OF INTEREST}

The authors declare that they have no conflict of interest.

\section{REFERENCES}

Beak DG, Hwang SI, Rhim EK, et al. Clinical Study on 1 Case of Reflux Wsophagitis. Korean J Oriental Physiology \& Pathology. 2004. 18: 1933-1937.

Bhagavan NV. Medical biochemistry. Academic Press, 2002.

Chien KJ, Su CH, Ho YC, et al. MAPKs-NF-kappaB Pathway Plays a Crucial Role in the Antiinflammatory Effects of Amentoflavone in Lipopolysaccharide-treated BV2 Microglia. Indian J Pharm Sci. 2018. 80: 204-210.

Cho YH, Kim HJ, Kim DI, et al. Effect of garlic (Allium sativum L.) stems on inflammatory cytokines, iNOS and COX-2 expressions in Raw 264.7 cells induced by lipopolysaccharide. Korean J Food Preserv. 2015. 22: 613-621.

Cho YS, Choi MG, Jeong JJ, et al. Prevalence and clinical spectrum of gastroesophageal reflux: a population-based study in Asan-si, Korea. Am J Fastroenterol. 2005. 100: 747-753.

Davies MJ, Hawkins CL. The Role of Myeloperoxidase in Biomolecule Modification, Chronic Inflammation, and Disease. Antioxid Redox Signal. 2020. 32: 957-981.

Fitzhugh OG, Nelson AA. Liver Tumors in Rats Fed Thiourea or Thioacetamide. Science. 1948. 108: 626-628.

Foye WO, Lemke TL. Foye's principles of medicinal chemistry. Lippincott Williams \& Wilkins. 2008.

Khan AA, Alsahli MA, Rahmani AH. Myeloperoxidase as an Active Disease Biomaker: Recent Biochemical and Pathological Perspectives. Med Sci (Basel). 2018. 6: 33-53.

Kim BM, Son SM. Mechanism of Developing Diabetic Vascular Complication by Oxidative Stress. Endocrinol Metab. 2006. 21: 448-459.

Kim DJ, Roh SS. Effect on Acute reflux Esophagitis by Evodiae Fructus Aquous Extract. Kor J Herbol. 2012. 27: 51-58.

Kim JS, Jang HS. The Expression Pattern of the Tight Junction Protein Occludin in the Epidermal Context When Comparing Various Physical Samples. Korean J Clin Lab Sci. 2015. 47: 267-272.

Kim SH. Anti-inflammatory effect of arecae semen extract through antioxidant pathway in reflux esophagitis rats. Daegu Haany University. 2019.

Kim ST, Ahn SH, Kim JD, Kim YK. Protective Effect of MeOH Extract of Evodia officinalis on Cyanide-induced Neurotoxicity in Cultured Neuroblastoma Cells. Kor J Pharmacogn. 2003. 34: 282-287.

Kim YH, Kim SY, Hwang MW. A Case Study of Taeumin Patient with Gastro-esophageal reflux disease (GERD) who Treated Successfully with Yeoldahanso-tang (Reduohanshao-tang). J of Sasang Constitutional Medicine. 2011. 23: 132-138.

Lee DS, Boo KH, Kim YC, et al. The Antiviral Effects of Areca catechu L. Extract. Korean J of Food Sci Technol. 2014. 46: 245-248.

Lee JA, Park HJ, Kim SH, et al. Evaluation of Evodiae Fructus Extract on the Chronic Acid Reflux Esophagitis in Rats. Kor J Herbol. 2019. 34: 15-23.

Lee JA, Shin MR, Lee JH, Roh SS. Effect of Coptidis Rhizoma and Evodiae Fructus Mixture on Esophageal Mucosa in Chronic Reflux Esophagitis. Kor J Pharmacogn. 2020. 51: 349-359.

Lee JA, Shin MR, Lee SN, Park SA, Park HJ. Effect of a Mixture of Rhei Rhizoma and Scutellariae Radix Extract on Acute Reflux Esophagitis Rats. Kor J Herbol. 2020. 35: 43-53.

Lin Q, Wang C, Jia Z, et al. UPLC-HDMS-based on serum metabolomics reveals the toxicity of arecae semen. J Ethnopharmacol. 2020. 247: 112223.

Omura N, Kashiwagi H, Chen G, Suzuki Y, Yano F, Aoki T. Estab- lishment of surgically induced chronic acid reflux esophagitis in rats. Scand J Gastroenterol. 1999. 34: 948-953.

Shin DH, Choi YH. Glutamine deprivation inhibits invasion of human prostate carcinoma LnCap cells through inactivation of matrix metalloproteinases and modulation of tight junctions. J Korean Soc Food Sci Nutr. 2013. 42: 1167-1174.

Shin MH, Kim ES, Lee YS. Suppressive Effects of Ulmi Pumilae Cortex Extracts on the Reflux Esophagitis in Rat. J Physiol \& Pathol Korean Med. 2016. 30: 257-265.

Roh SS, Seo BI. A philological study on poisoning of Arecae Serum. Journal of Jehan Oriental Medical Academy. 2012. 10: 69-81.

Vane JR, Bakhle YS, Botting RM. Cyclooxygenase 1 and 2. Annu Rev Pharmacol Toxicol. 1998. 38: 91-120.

Yang JY, Byeon HY, Kim JW, Kim SH, Lee PJ. Effect of Methanol Extract Concentration on the Anti-oxidative Activity and Toxicity of Evodiae Fructus to AGS Cells. J Korean Soc Food Cult. 2020. 35: 400-405.

Yang JY, Lee PJ, Kim JB. Effect of Evodiae fructus Methanol Extract on Virulence-Related Genes' Expression of Helicobacter pylori. Korean J Clin Lab Sci. 2019. 51: 316-322.

Yi SY, Lee SK, Kim MH, Han DS, Kim JW, Min YI. Epidemiologic 
Study of Reflux Esophagitis in General Health Screening People. J Int Korean Med. 1994. 36: 433-440.

Youn HS. The Anti-Inflammatory Effects of Phytochemicals by the Modulation of Innate Immunity. J Exp Biomed Sci. 2012. 18: 181-192.

Yun HJ, Heo SK, Lee YT, Paek WH, Park SD. Anti-inflammatory Effect of Evodia Officinalis DODE in Mouse Macrophage and Human Vascular Endotherial Cells. Kor J Herbol. 2008. 23: 29-38.

Zhang F, Yang P, He Q, Dong X, Zhang S. Is gastrointestinal motility related to alkaloids of Charred Semen Arecae? J Ethnopharmacol. 2020. 257: 112825.
Zhang S, Yang P, Li X, et al. Comparative Researches of Semen Arecae and Charred Semen Arecae on Gastrointestinal Motility, Motilin, Substance P, and CCL in Chronically Stressed Rats. Evid Based Complement Alternat Med. 2017. 2017: 1273561.

https://doi.org/10.15616/BSL.2021.27.2.77

Cite this article as: Lee JA, Shin MR, Park HJ, Roh SS. Effect of Evodiae Fructus and Arecae Semen Mixture on Esophageal Mucosa in Chronic Acid Reflux Esophagitis. Biomedical Science Letters. 2021. 27: 77-87. 